\title{
Effect of Helicobacter pylori infection and acid blockade by lansoprazole on clarithromycin bioavailability
}

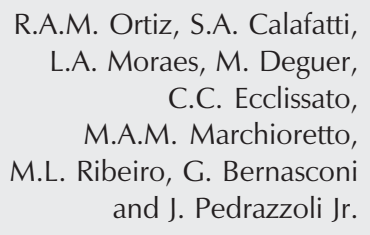

R.A.M. Ortiz, S.A. Calafatti, L.A. Moraes, M. Deguer, C.C. Ecclissato,

M.A.M. Marchioretto, M.L. Ribeiro, G. Bernasconi and J. Pedrazzoli Jr.

Unidade Integrada de Farmacologia e Gastroenterologia, Universidade São Francisco, Bragança Paulista, SP, Brasil

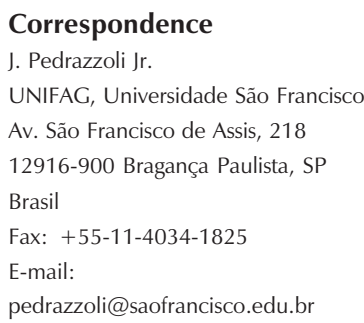

Correspondence

J. Pedrazzoli Jr.

UNIFAG, Universidade São Francisco

Av. São Francisco de Assis, 218

12916-900 Bragança Paulista, SP

Brasil

Fax: +55-11-4034-1825

E-mail:

pedrazzoli@saofrancisco.edu.br

R.A.M. Ortiz and S.A. Calafatti were supported by FAPESP.

Received December 14, 2005 Accepted December 6, 2006

\begin{abstract}
The effect of proton pump inhibitors and Helicobacter pylori infection on the bioavailability of antibiotics is poorly understood. We determined the effects of 5-day oral administration of $60 \mathrm{mg}$ lansoprazole on the bioavailability of clarithromycin in individuals with and without $H$. pylori infection. Thirteen H. pylori-infected and 10 noninfected healthy volunteers were enrolled in a study with an openrandomized two-period crossover design and a 21-day washout period between phases. Plasma concentrations of clarithromycin in subjects with and without lansoprazole pre-treatment were measured by liquid chromatography coupled to a tandem mass spectrometer. Clarithromycin $\mathrm{C}_{\max }$ and $\mathrm{AUC}_{0-10 \mathrm{~h}}$ were significantly reduced after lansoprazole administration. In addition, lansoprazole treatment of the H. pyloripositive group resulted in a statistically significant greater reduction in $\mathrm{C}_{\max }(40 v s 15 \%)$ and $\mathrm{AUC}_{0-10 \mathrm{~h}}(30 v \mathrm{vs} 10 \%)$ compared to lansoprazoletreated $H$. pylori-negative subjects. Thus, treatment with lansoprazole for 5 days reduced bioavailability of clarithromycin, irrespective of $H$. pylori status. This reduction, however, was even more pronounced in H. pylori-infected individuals.
\end{abstract}

Key words

- Clarithromycin

- Helicobacter pylori

- Lansoprazole

- Peptic ulcer

- Pharmacokinetics

Pharmacokinetics

\section{Introduction}

More than $50 \%$ of the world population is believed to be infected by Helicobacter pylori, the most common chronic bacterial infection in humans. This infection is a major pathogenic factor in gastroduodenal diseases, including chronic active gastritis, peptic ulcers and gastric neoplasm (1). Eradication is recommended for patients with symptomatic $H$. pylori infection and can be achieved by the combination of two antibiotics plus a proton pump inhibitor (2). $H$. pylori is capable of altering acid secretion and proton pump inhibitors have a more pronounced effect in $H$. pylori-infected than in non-infected individuals (3-5). Anti-secretory drugs such as proton pump inhibitors can potentially alter the pharmacokinetics of antibiotics by reducing the gastric juice viscosity and/or volume (6), affecting the chemical stability of drugs (7), slowing gastric 
emptying (8), and possibly reducing the dissolution of solid drug formulations.

Clarithromycin is commonly prescribed in most anti-H. pylori treatments (9). It is an advanced-generation macrolide with a broad in vitro antimicrobial spectrum. It also exhibits a broad spectrum of in vitro activity comparable with that of erythromycin and is active against most Gram-positive aerobic cocci and Gram-positive bacilli including mycobacteria, Gram-negative bacteria, some anaerobes, and chlamydiae (10). The activity of clarithromycin is enhanced by its extensive tissue distribution and by formation of the 14-(R)-hydroxyclarithromycin metabolite. Clarithromycin and 14-(R)-hydroxyclarithromycin have a minimum inhibitory concentration $\left(\mathrm{MIC}_{90}\right)$ of 0.03 and $0.06 \mu \mathrm{g} /$ $\mathrm{mL}$ for $H$. pylori, respectively (11). The drug is well absorbed from the gastrointestinal tract (12), but undergoes rapid degradation as a result of the low $\mathrm{pH}$ of the stomach (13). Therefore, elevation of the gastric $\mathrm{pH}$ might alter the bioavailability and distribution of clarithromycin.

The aim of the present study was to determine the effect of both lansoprazole administration and $H$. pylori infection on the pharmacokinetics of orally administered clarithromycin.

\section{Subjects and Methods}

\section{Subjects}

Twenty-three healthy volunteers (aged 19 to 35 years, height 165 to $180 \mathrm{~cm}$, weight 55 to $100 \mathrm{~kg}$ ) were selected after clinical examination and laboratory screening. The laboratory screening consisted of blood glucose, urea, creatinine, aspartate aminotransferase, alanine aminotransferase, gamma-glutamyl transpeptidase, alkaline phosphatase, total bilirubin, total protein, albumin, hemoglobin, hematocrit, total and differential white cell counts, routine urinalysis and serology for human immunodeficiency virus, hepatitis $\mathrm{C}$ virus, hepatitis B virus, and H. pylori. The serological test had a sensitivity of $92 \%$ and a specificity of $93.1 \%$ for Helicobacter (ImmunoComb II Helicobacter pylori IgG, Orgenics, Yavne, Israel). Thirteen of the individuals were $H$. pylori positive and 10 were $H$. pylori negative. The exclusion criteria included abnormalities in laboratory screening, previous gastric surgery or antibiotic use for eradication of $H$. pylori, use of antibiotics or proton pump inhibitors four weeks prior to the study, and a history of gastric ulcer or neoplasm. Written informed consent was obtained from each volunteer prior to the study, and the protocol was approved by the Universidade São Francisco Ethics Committee in accordance with the Declaration of Helsinki and Brazilian law.

\section{Lansoprazole administration}

The study had an open-randomized twoperiod crossover design, with a 21-day washout period between phases. In the LANS(-) phase (no lansoprazole pre-treatment), the volunteers were hospitalized at 9:00 pm after having had a regular evening meal. Following an overnight fast, they received a single tablet of clarithromycin $(500 \mathrm{mg}$ Klaricid $^{\circledR}$; Abbott, São Paulo, SP, Brazil) with $200 \mathrm{~mL}$ water at 7:00 am. During the LANS(+) phase (lansoprazole pre-treatment), the volunteers came to the clinical pharmacology and gastroenterology unit daily for 5 days (Monday to Friday), where they received one capsule of lansoprazole (30 mg Ogastro $^{\mathrm{TM}}$; Abbott) at 9:00 am and 20:00 pm. On Friday evening, they were admitted to the Clinical Pharmacology and Gastroenterology Unit, and received another capsule of lansoprazole at 9:00 pm. After an overnight fast, clarithromycin was administered as described above for the LANS(-) group.

During both study periods, blood samples $(10 \mathrm{~mL})$ with EDTA for plasma clarithromycin quantification were taken from a convenient forearm vein before and $0.5,1,1.5$, 2.0, 2.5, 3, 3.5, 4, 6, 8, and $10 \mathrm{~h}$ following 
clarithromycin administration. The samples were centrifuged at 2,000 $\mathrm{g}$ for $10 \mathrm{~min}$, and plasma was separated and stored at $-70^{\circ} \mathrm{C}$ until assayed for clarithromycin content by high-performance liquid chromatography (HPLC)-mass spectrometry.

\section{Sample extraction procedure}

Two hundred microliters of plasma was extracted after adding $50 \mu \mathrm{L}$ internal standard (erythromycin, $10 \mu \mathrm{g} / \mathrm{mL}$ ) and $50 \mu \mathrm{L} 0.1$ $\mathrm{M} \mathrm{NaOH}$ and $1 \mathrm{~mL}$ ethyl acetate. The tubes were vortex-mixed briefly and allowed to stand at room temperature for $5 \mathrm{~min}$. The tubes were then centrifuged at $10,000 \mathrm{rpm}$ for $10 \mathrm{~min}$ at room temperature. The upper organic layer was carefully removed and $200 \mu \mathrm{L}$ acetonitrile was added to the tubes followed by vortex-mixing for $15 \mathrm{~s}$ to reconstitute the residue. The solutions were transferred to microvials, capped and placed in an autosampler rack. Aliquots of $10 \mu \mathrm{L}$ were injected automatically into the HPLC.

\section{Preparation of standard solutions and reagents}

Clarithromycin standards were prepared by dilution from a stock solution of $100 \mu \mathrm{g} /$ $\mathrm{mL}$. The internal standard (erythromycin) was prepared by dilution from a stock solution $(100 \mu \mathrm{g} / \mathrm{mL})$ in acetonitrile to a final concentration of $10 \mu \mathrm{g} / \mathrm{mL}$.

\section{Preparation of calibration and quality control samples}

The limit of quantification of clarithromycin was $10 \mathrm{ng} / \mathrm{mL}$ and the lower limit of detection was $2 \mathrm{ng} / \mathrm{mL}$. Calibration standards were prepared by spiking control human plasma with standard solutions containing clarithromycin to give standards of 100 , $500,1000,1500,3000$, and $5000 \mathrm{ng} / \mathrm{mL}$. A fixed amount of erythromycin was added to all assay tubes as an internal standard. The calibration standards and blanks were freshly prepared for each assay and were extracted at the same time as the plasma samples and quality controls. Quality control samples were prepared by spiking control human plasma with 300, 2000, and $4000 \mathrm{ng} / \mathrm{mL}$ clarithromycin. One quality control sample for each of the three concentrations in every assay was thawed and extracted with the plasma samples.

Under these conditions, the calibration curves for clarithromycin in plasma (100$5000 \mathrm{ng} / \mathrm{mL}$ ) presented a straight line through the origin with a correlation of 0.9997 . Intraand interassay coefficients of variation were 3 and $9 \%$, respectively.

\section{Mass spectrometry and chromatography conditions}

An HPLC model PRO STAR 410 system (Varian, Walnut Creek, CA, USA) equipped with a Polaris $\mathrm{C} 18$ analytical column $(3 \mu \mathrm{m}$, $30 \mathrm{~mm} \times 2.0 \mathrm{~mm}, \mathrm{ID}, \mathrm{C} 18$ Genesis guard column, $4 \mu \mathrm{m}, 10 \mathrm{~mm} \times 4 \mathrm{~mm}$, ID; Jones Chromatography, Hengoed, UK) was used. The mobile phase consisted of $10 \mathrm{mM}$ ammonium acetate in water $(20 \%)$ and acetonitrile (80\%). The column was eluted isocratically at $0.1 \mathrm{~mL} / \mathrm{min}$ at room temperature. Total run time was $3.0 \mathrm{~min}$. The temperature of the autosampler was maintained at $20^{\circ} \mathrm{C}$ and the injection volume was $10 \mu \mathrm{L}$. A wash bottle containing freshly prepared 50\% acetonitrile in water was used to wash the autosampler needle to prevent a carry over effect.

Mass spectrometry was performed using an LC 1200 triple-stage quadrupole mass spectrometer, equipped with ESI electrospray source operating in the positive-ion mode using a cross flow as the counter electrode (Varian). The mass spectrometric conditions (tuning and collision-induced dissociation) for all compounds studied were optimized with standard solutions in the mobile phase $(5 \mu \mathrm{g} / \mathrm{mL}$ each at a flow rate of 10 $\mu \mathrm{L} / \mathrm{min}$ ) using an infusion pump connected 
directly to the electrospray probe.

The full-scan single mass spectrum was obtained after the infusion of pooled plasma following the intravenous administration of clarithromycin. The retention times for erythromycin and clarithromycin in the mass spectrometer were 1.1 and 1.4 min, respectively. The mass spectrometer was operated in the positive mode (ES+) and set for multiple reactions monitoring the following ions $(\mathrm{m} /$ z); $734.0>576.0$ for erythromycin and 748.5 $>590.0$ for clarithromycin. The dwell time was set at $0.8 \mathrm{~s}$, the cone voltage was $30 \mathrm{~V}$ and the collision energy and gas pressure (Argon) were $20 \mathrm{eV}$ and $2.02 \mathrm{~m}$ Torr, respectively.

\section{Pharmacokinetic and statistical analysis}

Maximum plasma concentration $\left(\mathrm{C}_{\max }\right)$ and the time taken to reach it $\left(\mathrm{T}_{\max }\right)$ were obtained directly from the individual concentration $v s$ time curves. A first-order terminal elimination rate constant $\left(k_{\mathrm{e}}\right)$ for clarithromycin was derived by log-linear regression of selected data points from the concentration $v s$ time curves describing a terminal log-linear decaying phase. The half-life $\left(\mathrm{T}_{1 / 2}\right)$ was estimated from this rate constant $\left(\mathrm{T}_{1 / 2}=\right.$ $\ln (2) / k_{\mathrm{e}}$ ). The respective area under the timeconcentration curves from 0 to $10 \mathrm{~h}$ for clarithromycin $\left(\mathrm{AUC}_{0-10 \mathrm{~h} \text { CLA }}\right)$ were calculated by the linear trapezoidal method using a non-compartmental pharmacokinetic model and performed by the addition of the $\mathrm{C}_{2 \mathrm{~h}} / k_{\mathrm{e}}$ value, where $\mathrm{C}_{10 \mathrm{~h}}=$ plasma CLA concentration $10 \mathrm{~h}$ following clarithromycin administration. The area under the time-concentration curves was also extrapolated to infinite $\left(\mathrm{AUC}_{0-\infty \mathrm{CLA}}\right)(14)$. All variables were analyzed by parametric (one-way ANOVA) and non-parametric tests (15). Parametric

Table 1. Clarithromycin pharmacokinetic parameters in plasma after a single oral $(500 \mathrm{mg})$ dose of clarithromycin in Helicobacter pylori-positive and H. pylori-negative volunteers with (LANS(+)) and without (LANS(-)) lansoprazole pre-treatment.

\begin{tabular}{|c|c|c|c|c|}
\hline \multirow[t]{2}{*}{ Variables } & \multicolumn{2}{|c|}{ H. pylori-positive $(\mathrm{N}=13)$} & \multicolumn{2}{|c|}{ H. pylori-negative $(\mathrm{N}=10)$} \\
\hline & LANS(-) & LANS(+) & LANS(-) & LANS(+) \\
\hline $\mathrm{AUC}_{0-10 \mathrm{~h}}\left(\mathrm{ng} \mathrm{h}^{-1} \mathrm{~mL}^{-1}\right)$ & 12598.44 & $8805.98^{*}$ & 14370.75 & 12932.55 \\
\hline Geometric mean $(90 \% \mathrm{Cl})$ & $\begin{array}{l}11068.38 \text { to } \\
16709.09\end{array}$ & $\begin{array}{l}7384.54 \text { to } \\
12761.25\end{array}$ & $\begin{array}{l}11989.11 \text { to } \\
18216.40\end{array}$ & $\begin{array}{l}11023.93 \text { to } \\
16429.58\end{array}$ \\
\hline $\mathrm{AUC}_{0-\infty}\left(\mathrm{ng} \mathrm{h}^{-1} \mathrm{~mL}^{-1}\right)$ & 17634.12 & $22501.10^{*}$ & 19308.07 & 19379.95 \\
\hline Geometric mean $(90 \% \mathrm{Cl})$ & $\begin{array}{l}14582.96 \text { to } \\
25973.05\end{array}$ & $\begin{array}{l}14053.89 \text { to } \\
42227.06\end{array}$ & $\begin{array}{l}16009.16 \text { to } \\
24563.26\end{array}$ & $\begin{array}{l}16485.56 \text { to } \\
23728.02\end{array}$ \\
\hline $\mathrm{C}_{\max }(\mathrm{ng} / \mathrm{mL})$ & 2258.45 & $1366.87^{\star}$ & 2352.80 & 2006.35 \\
\hline Geometric mean $(90 \% \mathrm{Cl})$ & $\begin{array}{l}2010.41 \text { to } \\
2817.51\end{array}$ & $\begin{array}{l}1139.93 \text { to } \\
2003.54\end{array}$ & $\begin{array}{l}1974.37 \text { to } \\
3006.48\end{array}$ & $\begin{array}{l}1703.67 \text { to } \\
2614.27\end{array}$ \\
\hline $\mathrm{T}_{1 / 2}(\mathrm{~h})$ & 4.82 & $8.39^{\star}$ & 4.59 & 4.68 \\
\hline Geometric mean $(90 \% \mathrm{Cl})$ & 3.75 to 6.88 & 0.28 to 31.68 & 4.18 to 5.12 & 4.25 to 5.23 \\
\hline $\mathrm{T}_{\max }(\mathrm{h})$ & 1.80 & 2.83 & 1.96 & 2.30 \\
\hline Geometric mean $(90 \% \mathrm{Cl})$ & 1.58 to 2.27 & 0.81 to 8.02 & 1.70 to 2.40 & 1.41 to 4.49 \\
\hline
\end{tabular}

${ }^{*} \mathrm{P}<0.05$ compared to LANS(-) patients (one-way ANOVA). Note: In contrast to $H$. pylori-positive patients, LANS had no statistically significant effect on the pharmacokinetics of clarithromycin in $H$. pylori-negative subjects. $90 \% \mathrm{Cl}=$ confidence interval at $90 \% ; \mathrm{AUC}_{0-10 \mathrm{~h}}$ and $\mathrm{AUC}_{0-\infty}=$ area under the time-concentration curves from 0 to $10 \mathrm{~h}$ for clarithromycin and extrapolated to infinite, respectively; $\mathrm{C}_{\max }=$ maximum plasma concentration; $T_{1 / 2}=$ half-life estimated as $T_{1 / 2}=\ln (2) / k_{e}$, where $k_{e}$ is the rate constant; $T_{\max }=$ time taken to reach the $C_{\max }$. 
and non-parametric tests were also used to compare $\mathrm{AUC}_{0-10 \mathrm{~h} \text { CLA }}$ and $\mathrm{C}_{\max }$ data. Individual $\mathrm{AUC}_{0-10 \mathrm{~h}}, \mathrm{C}_{\max }, \mathrm{T}_{1 / 2}, k_{\mathrm{e}}$ ratios, and $\mathrm{T}_{\max }$ differences between the LANS(+) (test) and LANS(-) (reference) phases were calculated.

We used the assessment of bioequivalence to evaluate whether a pharmacokinetic interaction had taken place. To prove bioequivalence there must be no difference between the bioavailability of clarithromycin before ("reference") and after lansoprazole administration ("test"). A 90\% confidence interval approach, the bioequivalence interval, was used to compare the bioavailability of clarithromycin before and after lansoprazole administration and a $90 \%$ confidence limit was estimated for the sample means. For considering bioequivalence, there should also be no statistical differences between the mean $\mathrm{AUC}_{0-10 \mathrm{~h}} \mathrm{AUC}_{0-\infty}$ and $\mathrm{C}_{\max }$. A P value of 0.05 was taken as the significance level for all statistical tests performed. ANOVA and the Mann-Whitney test were used.

\section{Results}

No side effects were reported by any of the volunteers after the administration of either lansoprazole or clarithromycin. The clinical and biochemical data of patients and volunteers were not affected by drug administration and remained within the reference values of the laboratories.

The pharmacokinetic parameters for clarithromycin were similar in $H$. pylori-positive or -negative volunteers before acid suppression (Table 1). A 5-day treatment with lansoprazole adversely affected the relative bioavailability of the antibiotic, as indicated by a reduction in the peak plasma concentration $\left(\mathrm{C}_{\max }\right)$ of clarithromycin, by the lack of inclusion within the $90 \%$ confidence interval for $\mathrm{AUC}_{0-10 \mathrm{~h} \mathrm{CLA}}, \mathrm{C}_{\max }$ and the individual $\mathrm{AUC}_{0-\infty} \mathrm{CLA}$ values in the range of $80-125 \%$, as well as the LANS(-)/LANS(+) ratio for $\mathrm{C}_{\max }$ and $\mathrm{AUC}_{0-10 \mathrm{hCLA}}$. Lansoprazole administration reduced the bioavailability of clari- thromycin in both groups of individuals; however, this reduction was even more pronounced in $H$. pylori-infected individuals (Table 2).

In addition, lansoprazole treatment in the $H$. pylori-positive group resulted in a significant $(\mathrm{P}<0.05)$ reduction in $\mathrm{C}_{\max }$ and $\mathrm{AUC}_{0-10 \mathrm{~h} \text { CLA }}$ compared to lansoprazoletreated $H$. pylori-negative subjects (Table 1 ).

\section{Discussion}

Until now, two studies have evaluated the pharmacokinetic interaction between a proton pump inhibitor and clarithromycin. Gustavson et al. (11) evaluated the pharmacokinetics of clarithromycin and its main active metabolite, 14-(R)-hydroxyclarithromycin, at steady state, with and without omeprazole administration in $H$. pylori-negative healthy male volunteers, concluding that omeprazole increased their bioavailability. More recently, Mainz et al. (16) investigated the pharmacokinetics of lansoprazole, amoxicillin, clarithromycin, and 14-(R)-hydroxyclarithromycin after 5 days of administration to uninfected volunteers, when given simultaneously (16) and observed an increase in 14-(R)-hydroxyclarithromycin and lansoprazole bioavailability. We did not measure 14-(R)-hydroxyclarithromycin concentrations. It is well known that this metabolite has in vitro activity against $H$. pylori; the MIC for this metabolite, however, is higher

Table 2. Bioequivalence analysis of clarithromycin (CLA) in Helicobacter pylori-positive and $H$. pylori-negative volunteers with (LANS(+)) and without (LANS(-)) lansoprazole pre-treatment.

\begin{tabular}{lcccccc} 
LANS(+)/LANS(-) & \multicolumn{2}{c}{ H. pylori-positive $(\mathrm{N}=13)$} & & H. pylori-negative $(\mathrm{N}=10)$ \\
\cline { 2 - 3 } & $\begin{array}{c}\text { Geometric } \\
\text { mean }\end{array}$ & $90 \% \mathrm{Cl}$ & & $\begin{array}{c}\text { Geometric } \\
\text { mean }\end{array}$ & $90 \% \mathrm{Cl}$ \\
\hline $\mathrm{C}_{\max }(\mathrm{ng} / \mathrm{mL})$ & 62.74 & $49.69-79.21$ & & 85.27 & $61.74-117.79$ \\
$\mathrm{AUC}_{0-10 \mathrm{~h}\left(\mathrm{ng} \mathrm{h}^{-1} \mathrm{~mL}^{-1}\right)}$ & 71.37 & $52.08-97.75$ & & 51.66 & $68.74-117.81$ \\
$\mathrm{AUC}_{0-\infty}\left(\mathrm{ng} \mathrm{h}^{-1} \mathrm{~mL}^{-1}\right)$ & 114.00 & $78.22-166.10$ & & 101.73 & $86.37-119.78$ \\
\hline
\end{tabular}

For abbreviations, see legend to Table 1. 
than that observed for its parent compound (0.06 vs $0.03 \mathrm{mg} / \mathrm{L})$ (10). Since H. pylori is not supposed to interfere with the hepatic metabolism of drugs and the bioavailability of clarithromycin was even lower in infected individuals than in non-infected ones after lansoprazole administration, a reduction of plasma 14-(R)-hydroxyclarithromycin concentrations is also to be expected. The observed reduction in clarithromycin bioavailability and the increase in $\mathrm{AUC}_{0-\infty}$ and $\mathrm{T}_{\text {max }}$ after lansoprazole administration suggest a reduction, and the delay of its absorption strongly suggests that the reduced bioavailability of clarithromycin after lansoprazole administration was induced during the biopharmaceutical phase, i.e., before absorption.

The discrepancies between these studies and ours may be partially explained by the analytical methods employed (liquid chromatography coupled to tandem mass spectrometry $v s$ liquid chromatography) with different quantification limits $(10 \mathrm{ng} / \mathrm{mL}$ in our study, $500 \mathrm{ng} / \mathrm{mL}$ in the study by Mainz et al. (16)), different clarithromycin formulations, study design (multiple doses/steady-state study vs single dose), differences in drug interaction (omeprazole/lansoprazole and clarithromycin), the concomitant use of amoxicillin in one of the studies (16), and by demographic characteristics of volunteers, such as age, which are directly correlated to plasma concentrations of clarithromycin and H. pylori status (17). It should also be stressed that $H$. pylori-infected individuals presented a more pronounced effect of lansoprazole on clarithromycin pharmacokinetics and ours was the only study evaluating these indi- viduals.

The efficacy of clarithromycin is suggested to be related to a time above MIC for at least 40 to $50 \%$ of the dosing interval in otitis media $(18,19)$. According to our results, this was not achieved after lansoprazole pre-treatment if one considers the MIC for clarithromycin to be $>2 \mu \mathrm{g} / \mathrm{mL}$ in our patients $(20,21)$, if the same relationship applies to $H$. pylori infection. Despite presenting a reduced bioavailability when associated with lansoprazole, eradication therapies containing these two drugs plus amoxicillin have eradication rates similar to those achieved when other proton pump inhibitors are used (22). Therefore, the reduction of clarithromycin bioavailability after lansoprazole administration appears to be clinically irrelevant for $H$. pylori eradication regimens. On the other hand, if the observed reduction of the bioavailability of clarithromycin during lansoprazole administration is relevant for the therapy of other infections remains to be determined.

Our results suggest that other mechanisms of action are also important for clarithromycin activity when used in association with proton pump inhibitors against $H$. pylo$r i$. Other possibilities may include a direct mechanism of action, the postulated bactericidal activity $(23,24)$ or even the importance of clarithromycin transfer from blood to gastric lumen, as described by our group and others (25). Studies performed in a clinical setting may be needed for a better understanding of the possible interactions that may occur among drugs ordinarily used in multi-drug schedules.

\section{References}

1. NIH Consensus Conference. Helicobacter pylori in peptic ulcer disease. NIH Consensus Development Panel on Helicobacter pylori in Peptic Ulcer Disease. JAMA 1994; 272: 65-69.

2. Penston JG, McColl KE. Eradication of Helicobacter pylori: an objective assessment of current therapies. Br J Clin Pharmacol 1997;
43: 223-243.

3. el-Omar EM, Penman ID, Ardill JE, Chittajallu RS, Howie C, McColl KE. Helicobacter pylori infection and abnormalities of acid secretion in patients with duodenal ulcer disease. Gastroenterology 1995; 109: 681-691. 
4. el-Omar EM, Oien K, El-Nujumi A, Gillen D, Wirz A, Dahill S, et al. Helicobacter pylori infection and chronic gastric acid hyposecretion. Gastroenterology 1997; 113: 15-24.

5. Kuipers EJ. Helicobacter pylori and the risk and management of associated diseases: gastritis, ulcer disease, atrophic gastritis and gastric cancer. Aliment Pharmacol Ther 1997; 11 (Suppl 1): 71-88.

6. Goddard AF, Spiller RC. The effect of omeprazole on gastric juice viscosity, $\mathrm{pH}$ and bacterial counts. Aliment Pharmacol Ther 1996; 10: 105-109.

7. Erah PO, Goddard AF, Barrett DA, Shaw PN, Spiller RC. The stability of amoxycillin, clarithromycin and metronidazole in gastric juice: relevance to the treatment of Helicobacter pylori infection. $J$ Antimicrob Chemother 1997; 39: 5-12.

8. Benini L, Castellani G, Bardelli E, Sembenini C, Brentegani MT, Caliari S, et al. Omeprazole causes delay in gastric emptying of digestible meals. Dig Dis Sci 1996; 41: 469-474.

9. Peterson WL, Graham DY, Marshall B, Blaser MJ, Genta RM, Klein PD, et al. Clarithromycin as monotherapy for eradication of Helicobacter pylori: a randomized, double-blind trial. Am J Gastroenterol 1993; 88: 1860-1864

10. Fraschini F, Scaglione F, Demartini G. Clarithromycin clinical pharmacokinetics. Clin Pharmacokinet 1993; 25: 189-204.

11. Gustavson LE, Kaiser JF, Edmonds AL, Locke CS, DeBartolo ML, Schneck DW. Effect of omeprazole on concentrations of clarithromycin in plasma and gastric tissue at steady state. Antimicrob Agents Chemother 1995; 39: 2078-2083.

12. Chu SY, Deaton R, Cavanaugh J. Absolute bioavailability of clarithromycin after oral administration in humans. Antimicrob Agents Chemother 1992; 36: 1147-1150.

13. Rowland M, Tozer TN. Clinical pharmacokinetics. Concepts and applications. 3rd edn. Baltimore: Williams \& Wilkins; 1995.

14. Hauschke D, Steinijans VW, Diletti E. A distribution-free procedure for the statistical analysis of bioequivalence studies. Int $\mathrm{J}$ Clin Pharmacol Ther Toxicol 1990; 28: 72-78.

15. Schall R, Hundt HK, Luus HG. Pharmacokinetic characteristics for extent of absorption and clearance in drug/drug interaction studies.
Int J Clin Pharmacol Ther 1994; 32: 633-637.

16. Mainz D, Borner K, Koeppe P, Kotwas J, Lode H. Pharmacokinetics of lansoprazole, amoxicillin and clarithromycin after simultaneous and single administration. J Antimicrob Chemother 2002; 50: 699706.

17. Nakagawa $\mathrm{Y}$, Itai S, Yoshida T, Nagai T. Physicochemical properties and stability in the acidic solution of a new macrolide antibiotic, clarithromycin, in comparison with erythromycin. Chem Pharm Bull 1992; 40: 725-728.

18. Craig WA, Andes D. Pharmacokinetics and pharmacodynamics of antibiotics in otitis media. Pediatr Infect Dis J 1996; 15: 255-259.

19. Burgess DS. Pharmacodynamic principles of antimicrobial therapy in the prevention of resistance. Chest 1999; 115: 19S-23S.

20. Mendonca S, Ecclissato C, Sartori MS, Godoy AP, Guerzoni RA, Degger $\mathrm{M}$, et al. Prevalence of Helicobacter pylori resistance to metronidazole, clarithromycin, amoxicillin, tetracycline, and furazolidone in Brazil. Helicobacter 2000; 5: 79-83.

21. Ecclissato C, Marchioretto MA, Mendonca S, Godoy AP, Guersoni RA, Deguer M, et al. Increased primary resistance to recommended antibiotics negatively affects Helicobacter pylori eradication. Helicobacter 2002; 7: 53-59.

22. Langtry HD, Wilde MI. Lansoprazole. An update of its pharmacological properties and clinical efficacy in the management of acidrelated disorders. Drugs 1997; 54: 473-500.

23. Pedrazzoli J Jr, Calafatti SA, Ortiz RA, Dias FE, Deguer M, Mendes $F D$, et al. Transfer of clarithromycin to gastric juice is enhanced by omeprazole in Helicobacter pylori-infected individuals. Scand J Gastroenterol 2001; 36: 1248-1253.

24. Nakao M, Malfertheiner P. Growth inhibitory and bactericidal activities of lansoprazole compared with those of omeprazole and pantoprazole against Helicobacter pylori. Helicobacter 1998; 3: 2127.

25. Endo H, Yoshida H, Ohmi N, Ohta K, Higuchi S, Suga T. Localization of $\left[{ }^{14} \mathrm{C}\right]$ clarithromycin in rat gastric tissue when administered with lansoprazole and amoxicillin. J Antimicrob Chemother 2002; 50: $285-288$. 